\title{
Editorial
}

\section{Acerca de los quartiles y la corriente principal}

Universitas Psychologica ingresó al Journal Citation Reports (JCR) de Thomson-Reuters en el cuartil 2 (Q2) con un Factor de Impacto (FI) de 1.283. Esta posición es la más alta de una revista multidisciplinaria en Latinoamérica y la segunda en Iberoamérica. El JCR es una herramienta que permite conocer los indicadores de citación de la revista y permite a un editor seguir la dinámica de consumo de los contenidos de la misma para tomar decisiones de gestión científica y editorial. En este mismo sentido, el puntaje le indica a un investigador el prestigio y la confianza que otros investigadores le dan al conocimiento que en ella se gestiona y por tanto puede guiar características tales como dónde publicar, ya que los investigadores desean que su conocimiento tenga un ámbito mayor de visibilidad.

Es claro que las citas son un indicador importante que dan cuenta de la apropiación académica del conocimiento. También es bueno precisar que la frecuencia de citas no permite identificar todo lo que deseamos entender de la forma como esta apropiación se da, y que es necesario identificar los tiempos en los que llegan las citas, de dónde llegan estas citas (autores, instituciones, revistas y libros) e incluso quién las produce y cuál es el contexto de las mismas.

La complejidad del tema condujo, hace ya más de 40 años, al desarrollo del factor de impacto (FI). Garfield desarrolló una forma sencilla de evaluar el impacto de una revista en una comunidad académica. Así, propuso relacionar el número de citas que obtiene una revista, con el número de artícu- los en un periodo determinado. Sin embargo, esta primera fórmula con la virtud de la sencillez no da cuenta de, por ejemplo, el tipo de prácticas de una comunidad, y es claro que historiadores, filósofos o sociólogos no tienen las mismas prácticas que médicos o físicos. No obstante, ha resultado útil como indicador de consumo de contenidos; el problema está en el uso del indicador como un marcador absoluto de prestigio y esto lo terminan construyendo las comunidades ligadas a la producción, el uso y la gestión de la investigación.

En este sentido, se han desarrollado diversos indicadores para mejorar la evaluación de las revistas. Por lo tanto, es necesario no solo comparar las revistas dentro de su propia área disciplinar (SNIP), sino, además, dar un peso diferencial al lugar donde surge la cita (SJR). Es claro que no es lo mismo recibir una cita de una revista que tenga un mayor impacto dentro de una comunidad que de otra.

Dentro de esta dinámica, resulta de especial relevancia la organización de las categorías por cuartiles, porque permite identificar rangos más que valores discretos en los que una revista se encuentra con relación a otras de la misma área temática. En este sentido, una revista en el cuarto cuartil (Q4) puede estar indicándonos que sus contenidos son una fuente de diálogo menos denso por parte de los académicos e investigadores de una temática y, consecuentemente, en la medida en que una revista sube de cuartil muestra que la comunidad la usa en forma más significativa, sugiriendo además que es una fuente de diálogo 
disciplinar central. Así, es claro que una revista en cuartil 1 puede estar indicando que se encuentra en la corriente principal del diálogo académico.

Para el equipo editorial y científico de Universitas Psychologica es realmente muy importante y grato el reconocimiento que la comunidad hace con el ingreso al JCR en el cuartil dos del mismo. Por consiguiente, lo que esto significa es que nuestro trabajo se hará más exigente y nos proponemos, por tanto, ajustar los tiempos de evaluación y publicación, los procesos de evaluación serán más exigentes. En este sentido, tenemos ahora que movernos a sostener y mejorar el ámbito de diálogo que Universitas tiene hoy con la disciplina en el mundo.

Wilson López-López

Editor 


\section{Editorial On Quartiles and Mainstream}

Universitas Psychologica entered Thomson-Reuters' Journal Citation Reports (JCR) in Quartile 2 with an Impact Factor (IF) of 1.283, the highest for a multidisciplinary journal in Latin America and the second highest in Iberoamerica. The JCR is a tool that presents the citation indicator for a journal and allows the Editor to track the dynamics of content usage. The Editor can use this information to make scientific and editorial management decisions, and researchers can use it to learn about the prestige and confidence other researchers deposit on the knowledge carried by the journal, and therefore it may guide the researcher's decisions on where to publish, as researchers want their knowledge to have greater visibility.

It is clear that citations are an important indicator of academic usage of knowledge. It is also important to emphasize that citation frequency does not lead to a complete understanding of this usage, and that we need to identify when the citations are made, where do they come from (authors, institutions, journals, and books), and even who makes them and what their context is.

The complexity of this subject led, over 40 years ago, to the development of the Impact Factor (IF). Garfield developed a simple way to assess the impact of a journal in an academic community by relating the number of citations achieved by a journal to the number of articles in a given timeframe. Nevertheless, this first formula, while simple, does not account for a certain community's practices, for example, and it is clear that historians, philosophers and sociologists do not behave in the same way that medical doctors or physicists do. However, it has been useful as an indication of knowledge usage. The problem lies on the use of this indicator as an absolute marker of prestige, and this is done by the communities which produce, use and manage research.

In this sense, several indicators have been developed in order to assess journals, which not only compare journals in their own areas (SNIP), but also give differential weights to the origin of the citation (SJR). It is clear that it is not the same to get a citation from a higher impact journal in its community than from other.

This brings us to the relevance of quartile organization within the categories, which enables the identification of ranks, instead of discrete values, for placing a journal in comparison with other journals in its area. A $4^{\text {th }}$ quartile journal may carry less dense dialogues in a certain area, and as it ranks in higher quartiles, the community is using it in a more meaningful way and it should be regarded as a central journal in the disciplinary dialogue. It is clear that a $1^{\text {st }}$ quartile journal is basically in the mainstream of academic dialogue.

For the editorial and scientific team in Universitas Psychologica, entering JCR Q2 is a recognition made by the community, which we regard as very important and pleasant. This means that our work will become more demanding and we intend to adjust our review and publishing schedules. The reviewing processes will also be more demanding. 
We need to move towards keeping up and improving the dialogue we maintain with the discipline worldwide.

Wilson López-López

Editor 